\title{
Using Funds of Knowledge to Address Diversity Issues in STEM
}

Wendy Jackeline Torres, Jacqueline M. Gilberto, and Margaret E. Beier Rice University

Miner et al. (2018) call for industrial and organizational (I-O) psychologists to examine the societal structures that influence women's underrepresentation in STEM. Here we extend their ideas and suggest that diversity in STEM would benefit from considering how people develop within the context of their environment. Educational researchers refer to the knowledge people develop through daily experiences with their cultural milieu as funds of knowledge. Funds of knowledge essentially represent a person's expertise, and educational researchers have recognized that designing environments that draw from expertise facilitates success for students, including women and underrepresented minorities in STEM.

Here we (a) describe the funds of knowledge framework, (b) highlight the value of this framework in facilitating success in STEM, and (c) suggest a research agenda for using funds of knowledge to address diversity issues in STEM schools and organizations. Our contribution is in introducing funds of knowledge as a viable framework for examining the success of women and underrepresented minorities in STEM and more generally as a useful approach in I-O psychology.

\section{Funds of Knowledge}

Funds of knowledge is a theoretical framework introduced by González (2005), Moll, Amanti, Neff, and Gonzalez (1992), and Vélez-Ibáñez and Greenberg (2005), and is defined as the "historically accumulated and culturally developed bodies of knowledge and skills essential for household or individual functioning and well-being" (Moll et al., 1992, p. 133). Researchers and teachers work alongside students and their families to identify household knowledge and skills, and subsequently design classroom lesson plans and activities that draw upon the identified expertise (González, Moll, Tenery, et al., 2005). We refer readers to González, Moll, and Amanti (2005) for a comprehensive review.

Wendy Jackeline Torres, Department of Psychology, Rice University; Jacqueline M. Gilberto, Department of Psychology, Rice University; Margaret E. Beier, Department of Psychology, Rice University.

Correspondence concerning this article should be addressed to Wendy Jackeline Torres, Department of Psychology, Rice University, MS-25, P.O. Box 1892, 6100 Main Street, Houston, TX 77005.E-mail: jackietorres@rice.edu 


\section{Funds of Knowledge in STEM Education}

The funds of knowledge perspective acknowledges that students from backgrounds where role models (e.g., parents) successfully navigate established systems (i.e., school or work) will be more successful, not because they are smarter or more motivated per se but because they already have important knowledge that facilitates the transition from high school STEM education to college (e.g., how to network with professors and join research labs). By contrast, students from underrepresented backgrounds may have less exposure to traditional educational contexts through role models, which may negatively affect their performance in school. Moreover, the knowledge under-represented students likely possess - although varied and extensivemay not apply as readily to traditional postsecondary educational environments.

Research suggests classroom interventions that clearly connect students' funds of knowledge and STEM performance environments lead to more favorable outcomes for women and underrepresented minorities in STEM (see Verdin, Godwin, \& Capobianco [2016] for a review). That is, connecting classroom activities to students' lived experiences can support and enhance STEM learning and facilitate interest and positive beliefs about STEM (e.g., Basu \& Calabrese Barton, 2007; Mejia, Wilson-Lopez, Hailey, Hasbun, \& Householder, 2014; Stevens, Andrade, \& Page, 2016).

\section{Funds of Knowledge in STEM and Beyond}

STEM organizations-like all organizations-struggle to attract and retain a diverse workforce. Research questions that can be addressed through a funds of knowledge approach are shown in Table 1. Currently, sparse research demonstrates the application of expertise in the STEM classroom, and even fewer studies have examined the STEM organization (only 14 studies examining funds of knowledge in STEM education were found; see Verdin et al., 2016).

One consideration in the funds of knowledge approach is that it is essential to understand what students bring to the table in terms of existing knowledge. To identify students' expertise, I-O psychologists can further develop valid and reliable tools and methods that involve students and their families. Additionally, we need to identify the institutional changes that can be strategically designed to connect the experiences and strengths of students with the STEM curriculum.

More generally, organizational scientists have not typically focused on the funds of knowledge that make workers successful, and more effort is needed to define the knowledge construct and on knowledge measurement (Beier, Young, \& Villado, 2018). A greater understanding of what people know and the extent to which the environment can be tailored to use prior 
Table 1. Research Needs for Using Funds of Knowledge to Address Diversity Issues in STEM

\begin{tabular}{|c|c|c|}
\hline Category & Research area & Sample research questions \\
\hline \multirow[t]{4}{*}{ School } & $\begin{array}{l}\text { Students' funds of } \\
\text { knowledge as a } \\
\text { valuable resource }\end{array}$ & $\begin{array}{l}\text { How do we assess what students know? } \\
\text { How does gender affect prior } \\
\text { experiences and development of } \\
\text { expertise? }\end{array}$ \\
\hline & $\begin{array}{l}\text { Effective teaching } \\
\text { strategies }\end{array}$ & $\begin{array}{l}\text { How can educators use students' } \\
\text { knowledge as capital to facilitate better } \\
\text { outcomes? What knowledge, skills, } \\
\text { abilities, and resources will educators } \\
\text { need to effectively use funds of } \\
\text { knowledge in STEM learning? }\end{array}$ \\
\hline & & $\begin{array}{l}\text { Do classrooms that use students' funds of } \\
\text { knowledge (e.g., engineering design that } \\
\text { taps into students' prior experiences and } \\
\text { interests) lead to better learning and } \\
\text { persistence? }\end{array}$ \\
\hline & $\begin{array}{l}\text { Theoretical mechanism } \\
\text { between funds of } \\
\text { knowledge and STEM } \\
\text { success }\end{array}$ & $\begin{array}{l}\text { If use of prior knowledge is associated } \\
\text { with success in STEM programs, what } \\
\text { are the mechanisms that explain this } \\
\text { effect? Are the effects different between } \\
\text { women and men? }\end{array}$ \\
\hline \multirow[t]{4}{*}{ Organization } & $\begin{array}{l}\text { Selection and hiring } \\
\text { processes }\end{array}$ & $\begin{array}{l}\text { To what extent do selection and hiring } \\
\text { processes use workers' funds of } \\
\text { knowledge (e.g., inclusive job } \\
\text { descriptions, recruitment strategies that } \\
\text { value diverse prior experiences)? }\end{array}$ \\
\hline & Retention, job design & $\begin{array}{l}\text { How can organizations use funds of } \\
\text { knowledge to facilitate the retention of a } \\
\text { diverse workforce (e.g., job crafting } \\
\text { opportunities, seeking perspective and } \\
\text { expertise of women and } \\
\text { underrepresented workers in STEM)? }\end{array}$ \\
\hline & $\begin{array}{l}\text { Diversity and inclusion } \\
\text { in organizations }\end{array}$ & $\begin{array}{l}\text { In what ways can funds of knowledge be } \\
\text { used to support diversity in STEM } \\
\text { organizations (e.g., encouraging diverse } \\
\text { workstyles and approaches, change } \\
\text { perception of STEM field as a male } \\
\text { domain)? }\end{array}$ \\
\hline & & $\begin{array}{l}\text { What are the characteristics of } \\
\text { organizations that create an inclusive } \\
\text { environment (e.g., management } \\
\text { practices, meaningful work } \\
\text { assignments)? Which strategies are } \\
\text { more effective than others? }\end{array}$ \\
\hline
\end{tabular}


knowledge will potentially increase the fit between the worker and the work environment. For example, organizations can strategically tailor job tasks to use workers' prior experiences, such as when managers allow employees to use well-learned tools and/or processes rather than adopt those most prevalent in the organization and more generally when workers are strategically positioned in the organization in roles that capitalize on their unique skills and abilities. Similar to key challenges in educational environments, a key strategy in the funds of knowledge approach for working adults will be assessing worker funds of knowledge.

Because it permits students and workers to capitalize on a diverse set of prior knowledge and experience, the funds of knowledge approach has promise for increasing the participation of women in STEM education programs and organizations. However, more work is needed to understand how gender and status as an underrepresented minority would affect experiences that influence the development of funds of knowledge. The funds of knowledge approach suggests one active strategy in which instructors and managers can make the experiences, values, and interests of women and underrepresented minority students relevant.

\section{References}

Basu, S. J., \& Calabrese Barton, A. (2007). Developing a sustained interest in science among urban minority youth. Journal of Research in Science Teaching, 44(3), 466-489. doi: 10.1002/tea.20143

Beier, M. E., Young, C. K., \& Villado, A. J. (2018). Job knowledge: Its definition, development and measurement. In D. S. Ones, N. Anderson, C. Viswesvaran, \& H. K. Sinangil (Eds.), Handbook of industrial, work and organizational psychology: Personnel psychology and employee performance (pp. 279-298). London, UK: SAGE. doi: 10.4135/9781473914940

González, N. (2005). Beyond culture: The hybridity of funds of knowledge. In N. González, L. C. Moll, \& C. Amanti (Eds.), Funds of knowledge: Theorizing practices in households, communities, and classrooms. (pp. 29-46). Mahwah, NJ: Lawrence Erlbaum.

González, N., Moll, L. C., \& Amanti, C., Eds. (2005). Funds of knowledge: Theorizing practices in households, communities, and classrooms. Mahwah, NJ: Lawrence Erlbaum.

González, N., Moll, L., Tenery, M. F., Rivera, A., Rendón, P., Gonzales, R., \& Amanti, C. (2005). Funds of knowledge for teaching in Latino households. In N. González, L. C. Moll, \& C. Amanti, (Eds.), Funds of knowledge: Theorizing practices in households, communities, and classrooms. (pp. 89111). Mahwah, NJ: Lawrence Erlbaum.

Mejia, J. A., Wilson-Lopez, A., Hailey, C. E., Hasbun, I. M., \& Householder, D. L. (2014). Funds of knowledge in Hispanic students' communities and households that enhance engineering design thinking. Presented at the 2014 ASEE Annual Conference \& Exposition. Retrieved from https://peer.asee.org/funds-of-knowledge-in-hispanic-students-communitiesand-households-that-enhance-engineering-design-thinking

Miner, K. N., Walker, J. M., Bergman, M. E., Jean, V. A., Carter-Sowell, A., January, S. C., \& Kanaus, C. (2018). From "her" problem to "our" problem: Using an individual lens versus a social-structural lens to understand gender inequity in STEM. Industrial and Organizational Psychology: Perspectives on Science and Practice, 11(2), 267-290.

Moll, L. C., Amanti, C., Neff, D., \& Gonzalez, N. (1992). Funds of knowledge for teaching: Using a qualitative approach to connect homes and classrooms. Theory Into Practice, 31(2), 132-141. doi: 10.1080/00405849209543534 
Stevens, S., Andrade, R., \& Page, M. (2016). Motivating young Native American students to pursue STEM learning through a culturally relevant science program. Journal of Science Education and Technology, 25(6), 947-960. doi: 10.1007/s10956-016-9629-1

Vélez-Ibáñez, C., \& Greenberg, J. (2005). Formation and transformation of funds of knowledge. In N. González, L. C. Moll, \& C. Amanti (Eds.), Funds of knowledge: Theorizing practices in households, communities, and classrooms (pp. 47-69). Mahwah, NJ: Lawrence Erlbaum.

Verdin, D., Godwin, A., \& Capobianco, B. (2016). Systematic review of the funds of knowledge framework in STEM education. School of Engineering Education Graduate Student Series. Retrieved from http://docs.lib.purdue.edu/enegs/59

\title{
Addressing the STEM Problem in Ways That Work
}

\author{
Karan Saggi \\ Claremont McKenna College
}

Let's look at two solutions that should be effective in addressing the gender issue in STEM. First, early intervention works. Scientific and mathematical learning can, and should, be integrated into early childhood learning and development. Miner et al. (2018) mention the potential of nurturing a child's interest in STEM through early education. The challenge is that it is segregated by gender biases ("early schooling differences, parental choices in encouraging child interests and hobbies, and other early reinforcement differences that are societally based"; Miner et al., 2018, p. 270). According to Gunderson, Ramirez, Levine, and Beilock (2012) parents tend to expect that their boys are more gifted in STEM than their girls, even when their achievement levels do not differ objectively. The focus needs to shift from moving along with this gender bias to constructively using the gender difference.

Recognizing researched gender differences and incorporating them into early education can help understand how nurture can affect STEM learning and appetite. Henderlong and Lepper (2007) find that for girls, praising the product or the process of learning may be more beneficial in boosting motivation than praising the person. A change in the approach to praise can make or break motivation. For instance, "That's a great chart" may work better than "You're so smart." Doing the opposite can flatline motivation. Bronson and Merryman (2011) also seek out gender differences in nurturing and education. Dweck (2000) highlights that an "emphasis on challenge, effort, and

Karan Saggi, Kravis Leadership Institute, Claremont McKenna College.

Correspondence concerning this article should be addressed to Karan Saggi, Kravis Leadership Institute, Claremont McKenna College, 850 Columbia Avenue, Claremont, CA 91711. E-mail: ksaggi14@cmc.edu 